\title{
Students' Strategies in Reading Online Authentic Materials
}

\author{
Rahma Dania ${ }^{1 *}$ and Annisha Dyuli Adha ${ }^{2}$ \\ ${ }^{1}$ English Education Department, FKIP Universitas Putra Indonesia YPTK, Padang, Sumatra Barat 25221, Indonesia \\ ${ }^{2}$ English Education Department, FKIP Universitas Putra Indonesia YPTK, Padang, Sumatra Barat 25221, Indonesia \\ *Corresponding author. Email: rahmadania.azed@gmail.com
}

\begin{abstract}
Reading online authentic materials for first-year EFL students is not a piece of cake. They need to employ reading strategies they were learning in reading the authentic texts. The present study describes the implementation of reading strategies that are used by EFL freshmen in Reading Comprehension course. The type of this study is descriptive study and the participants were 22 students who were having Reading Comprehension class. The data were collected through interview and questionnaire. The result of this study revealed that the students use three main strategies, which are: 1) Scanning, 2) Previewing and Predicting, and 3) guessing word meaning. The result also revealed that scanning is the most common reading strategy used by the first-year EFL students in reading online authentic materials.
\end{abstract}

Keywords: Reading, Reading Strategies, Authentic Materials

\section{INTRODUCTION}

The importance of English language teaching is also influenced by the kind of materials teachers use in the classroom. The teachers could choose to use either authentic materials or non-authentic materials. It is already stated by many authors in their book and many researchers in their study that using authentic materials has many advantages in helping the students acquiring language in EFL classroom.

The term of authentic materials means every resource that can be used for pedagogical purposes while it is actually not designed to be used in language classroom [1]. Nowadays, the availability of authentic materials is so wide. The teacher can find authentic materials everywhere and every time through newspaper, magazines, and especially the internet.

Moreover, Harmer [2] stated that authentic materials are those which are created for native speakers. These materials are real texts and it does not design for language classroom. In other words, these real texts are not created for language teachers or language teaching. However, authentic materials could be used in EFL classroom to show to the students that the language they are studying is not only used in the classroom but also in real life [3].

Some findings related to using authentic materials in language classroom have been declared by many researchers. Syafri [4] found that applying authentic materials in ELT classroom helped the students improve their understanding of the language, and studying English through authentic materials awaken students' interest. Authentic materials also increase students' sensitivity and competence in the target language [5]. Using authentic materials could motivate students learning activities and was more effective than the use of non-authentic materials [4].

Moreover, Sulimah [3] argued that some students against the use of authentic materials. So the teacher should be creative to solve this problem. Besides, Syafri [4] also found that there are some problems faced by the teachers when they would like to use these kind of materials in their classroom. Using authentic materials means understanding other culture while sometimes students are not familiar with the other culture. The structure of the text also becomes a problem in using authentic materials.

In this digital era, finding authentic materials become easier since the teachers could search so many kinds of learning sources online. There is plethora online authentic reading materials that can be found on the internet. Meanwhile, in doing reading activity for reading comprehension class, the students' should be able to comprehend the text easily. Thus, this research is going to observe reading strategies used by the students in reading online authentic materials.

\section{LITERATURE REVIEW}

The word "authentic" in Cambridge Advanced Learner's Dictionary means 'it is real, true or what people say it is'. Meanwhile, Nunan [4] said that authentic materials mean all of spoken or written language sources that have been designed for real communication. This means that every data used in the target language are qualified enough to be described as authentic materials. 
In addition, Gebhard [6] stated that authentic materials consist of everything that used for communication purposes in real life. Lee [3] proposed that the materials are textually authentic if it is not written for teaching purposes, but for a real-life communicative purpose, when the writer has a certain message for the reader. Authentic materials are items designed for native speakers of English and were not designed for language students.

Moreover, authentic materials are every language data produced for real life communication purposes. They may contain false starts, and incomplete sentences. Though, they are useful for improving the communicative aspects of the language. Based on the definitions above, authentic materials can be any materials that are perceived by the learners as useful, give a picture about the real language use, and interesting in learning English.

Advantages of authentic materials in language learning have been observed by a lot of researchers. First, Syafri [4] stated that the advantage of using authentic materials in the classroom is to make students know the use of real language. It means that authentic materials give the learner proof that the language they are studying is real and not only studied in the classroom. Second, the students can get contextual language learning through using authentic materials in the classroom [3]. Students can get the chance to read, rehearse, practice, use and learn the language through the materials that they can see, examine and touch. They can enjoy learning about interesting places, viewing the photographs, reading the brochures, etc. without going to the places. Furthermore, Gebhard [6] also stated that authentic materials can reinforce students the direct relation between the language and their surroundings. Third, the students who use authentic materials can learn more on content and meaning than on language, it is a valuable source of language input [1]. Shepherd [3] also stated that using authentic materials is a relatively easy and convenient way to improve not only students' general skills, but also their confidence in a real situation.

In addition, Yuliana [7] found that another benefits of using authentic materials in the classroom is that these materials are motivating and challenging. Authentic materials had a positive effect on increasing students' motivation and made learning more enjoyable. Further, authentic materials used for teaching provide knowledge of society and culture.

Moreover, using authentic materials can encourage the learners to learn, provide exposure to real language, relate more closely to learners' needs, and support a more creative approach to teaching. In line with this idea, Peacock [8] discovered the use of authentic materials on the motivation of EFL learners indicates that their motivation in learning English increases significantly. When the authentic materials are effectively used, they help bring the real world into the classroom and enliven the English class significantly. In addition, using authentic materials can reinforce the direct relation between the language classroom and the outside world for the students; offer a way to contextualize language learning and a valuable source of language input [6]. Moreover, the exposure to a variety of vocabulary and structures will occur when using authentic materials in teaching English [9].

There are many kinds of authentic materials, especially online on the internet. Sources of authentic materials are not only limited to native speakers, magazines, and newspaper articles but also it can be recipes, brochures, announcement, maps, labels, menus, transportation schedules, song, film, literature, television program, radio broadcast, etc. Bringing authentic materials into the classroom can encourage students to learn the target language as it adds a real-life element to the student's learning experience [7].

The biggest challenge for teachers in using authentic materials is to find appropriate authentic materials for their students. Since a teacher as a mediator or facilitator [12], he or she should provide any materials to encourage the learners' learning of English. In line with this, it is important to have as many resources as possible in the classroom. Regarding the important function of the teacher in teaching, the teacher needs to provide the language input by exploiting the materials needed. The teacher who uses authentic materials, in this case, has the responsibility to carry or prepare the materials and distribute them to the students. Furthermore, the teacher should teach reading strategies to the students in order to be able to comprehend the reading text taken from online authentic materials.

\section{METHOD}

This study dealt with reading strategies used by the students in reading online authentic materials in reading comprehension course. In conducting the research, this study used qualitative research method. In collecting data, one of private universities in Padang, West Sumatera, was chosen as the research site. This research site was chosen based on several considerations. First, this chosen research site could provide feasibility in gaining the data since both researchers are teaching staffs of this university. Besides, as the teaching staffs, the researchers would be able to observe students' progression in doing reading activity. It also provides accessibility and would not give many problems for the researcher to manage the time in doing the research. In addition, this study involved reading comprehension course students consists of 24 students as the participants.

This study used questionnaire and interview to collect the data. Questionnaire was given to the students after several meetings of reading course. After that, 7 students who chose different strategies in the questionnaire were being interview. In analyzing the data, 
all of the data was classified, organized, and interpreted as in the manner of qualitative research method.

\section{RESULT AND DISCUSSION}

Reading and comprehending written text in a foreign language, in this case English, is not a piece of cake. Readers need the right strategy in understanding the reading, either in finding the information needed, in finding the main ideas or topics offered in the reading or to build a thorough understanding of the content of the reading text. Linguists come up with many theories for strategies for reading in English Language Teaching classroom. One of them is Mikulecky and Jeffries [10] who described several reading strategies such as previewing and predicting, skimming, scanning, guessing word meaning, finding the topic and main idea, finding the pattern of organization and using reference words. Students who take the Reading Comprehension II course have previously taken and passed the Reading Comprehension I course. In this course, students learn reading strategies proposed by Mikulecky and Jeffries [10]. Therefore, when doing reading activity in the form of online Authentic Materials, students are expected to be able to apply the strategies they have learned in their reading activities in Reading Comprehension II course. In this study, the researchers explored strategies used by the students in helping them understand English text, in this case reading online authentic materials. The researchers used questionnaire with some questions in the form of optional check box. It means that the researchers provided some answers and it can be selected more than by the student / research participant. Here is the most related question in the questionnaire regarding this title:

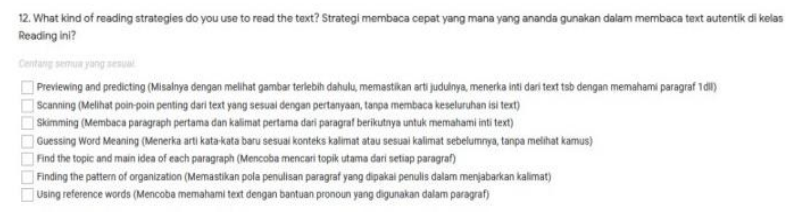

The question was written in English and Indonesian language. English language was used to state the atmosphere of English Language Teaching classroom. Meanwhile, Indonesian language was used in order to avoid students' confusion while choosing the answer. However, the answer was only written only in English assuming that the students/ research participants were familiar with the names of the strategies written in this question. Nonetheless, to re-call participants' knowledge of the aims and objectives of each reading strategy, the researcher provided a brief explanation of each strategy. This was expected to lead participants' answers to definite answers, not just a guess.

In reading English text, whether in reading activity by using reading text from the textbook or reading activity by using online authentic materials, all of the strategies mentioned in the questionnaire can be applied by the readers in their reading activity. Baker and Boonkit [11] stated that reading strategies are techniques that can help readers complete their reading faster and still have proper understanding. This is supported by the theory presented by Dewi and Salmiah [13] who said that in reading activities, students need right reading strategy in order to complete the reading process and can easily understand the content and purpose of the reading.

Mikulecky and Jeffries [10] suggest reading strategies that can help students understand English reading. The first strategy presented by Mikulecky and Jeffries is scanning. Scanning is a very fast reading strategy. This strategy can be used when the reader already has a question to look for in the text. In other words, this scanning strategy is used when the reader wants to find specific information contained in the reading. Therefore, readers do not need to read word by word in the text, but readers can focus on the core information that can answer the question. The second strategy is previewing and predicting. Previewing can be defined as reviewing the elements contained in a text. For example, before the reader starts their reading activity, they can briefly review the title of the reading, the author, pictures, maps or graphics in the text, and so on. After conducting a review, readers can predict the content of the reading. This strategy would take some time at the beginning of the reading activity, but by implementing this strategy, readers can understand the text faster and better.

The third reading strategy suggested by Mikulecky and Jeffries [10] and quoted in this study is finding topics and main ideas. Every good paragraph has one topic. Main idea is a complete sentence containing the topic and idea of the author. So, when readers can find the topic of a paragraph, it will be easier for the readers to infer the meaning of the text. The fourth strategy is finding the pattern of organization. Apart from containing one topic in one paragraph, good text also has writing patterns such as listing of ideas and examples, sequences, comparison/ contrast, and cause-effects. This writing pattern will help readers to be able to find topics and main ideas easily. The last strategy is skimming. Skimming is also a fast reading strategy. Skimming used to find the general information in a text.

The reading strategies were written in a research questionnaire involving 22 participants who were assigned to read authentic texts obtained from the internet. Participants have been taught to read online authentic materials for 7 (seven) meetings. The following are the results of 22 participants' responses to the strategies they used in reading comprehension of online authentic materials: 


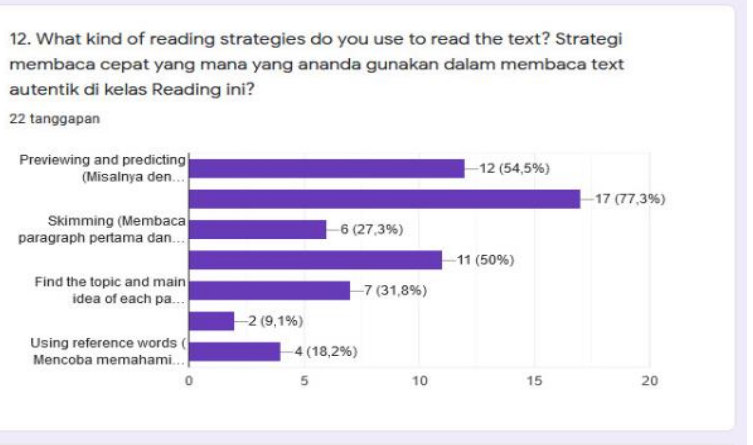

Figure 1 Reading Strategies used by students

Based on the graphic above, it can be concluded that scanning is the most used strategy applied by the students in reading authentic text. This strategy chose by 17 students out of 22 students. It can be seen from the graph that $77.3 \%$ of the participants utilized scanning as their reading strategy in reading online authentic materials in reading classroom. Further, the second and the third most used reading strategies chosen by the students were previewing and predicting and guessing meaning from context. There were 12 and 11 students who chose previewing and predicting and also guessing word meaning as their favorite strategies in reading online authentic text. The graph showed that there were $54.5 \%$ and $50 \%$ of participants chose these reading strategies.

Furthermore, aside from almost always said and taught together with scanning, skimming was not one of the favorite strategies used by the students in reading authentic materials. It can be seen from the data that only 6 out of 22 participants used skimming in their online authentic reading activity. In other words, there were only $27.3 \%$ of participants chose skimming as their reading strategy.

\section{CONCLUSION}

In reading any texts, readers need to employ a reading strategy in order to help them to comprehend the text easily. This is also important in reading online authentic materials. In reading online authentic texts, the students could use some reading strategies such as previewing and predicting, scanning, skimming, guessing the word meaning, finding the pattern of organization, etc.

This study attempted to observe what kind of strategy used by the students in reading online authentic materials. The data revealed that scanning is the most favorite reading strategy used by 22 students in their reading online authentic materials activity. The data also showed that scanning used by the students in their reading activity because the assignment almost always asked them to find some specific information in the text.
Meanwhile, the data proved that finding the pattern of organization was the least favorite reading strategy utilized by the students in doing reading of online authentic materials. This study found that this strategy was not really often used by the students because the assignment almost never asked them to explore the pattern of the paragraph.

\section{ACKNOWLEDGMENT}

This study was supported by President of YPTK and Rector of Universitas Putra Indonesia "YPTK" Padang.

\section{REFERENCES}

[1] J. C. Richard. Curriculum development in language teaching, 2nd Edition, Cambridge University Press, 2017.

[2] J. Harmer. The practice of english language teaching, Person Education Limited, 2015.

[3] R. Sulimah. The use of authentic materials in teaching reading comprehension (an experimental study at madrasah tsanawiyah negeri in pontianak), Master Thesis, Universitas Pendidikan Indonesia, 2009.

[4] M. Syafri. The use of authentic efl reading materials in teaching reading. an experimental study at a senior high school in sarolangun regency jambi province, Master Thesis, Universitas Pendidikan Indonesia, 2011.

[5] C. C. Hwang. Effective EFL education through popular authentic material, Asian EFL Journal. 7(1) (2005)

[6] J. G. Gebhard. Teaching English as a foreign or second language, The Univerity of Michigan Press, 2013.

[7] Yuliana. The use of authentic materials in teaching descriptive writing, Master Thesis, Universitas Pendidikan Indonesia, 2008

[8] M. Peacock. The effect of authentic materials on the motivation of EFL learners, ELT Journal. 51(2) (1997) 144-156. http://eltj.oxfordjournals.org/content/51/2/144.full.p $\underline{\mathrm{df}}$

[9] R. E. Larimer, L. Schleicher. New ways in using authentic materials in the classroom, TESOL Publications, 1999.

[10] B. S. Mikulecky, L. Jeffries. More reading power student book (3rd Edition), Pearson-Education, 2011.

[11] W. Baker, K. Boonkit. Learning strategies in reading and writing: EAP contexts, Relc. 35(3) 2004

[12] J. Harmer. How to teach English, Pearson Education Limited, 2007.

[13] U, Dewi, M, Salmiah. Students' reading strategies at English educational department, Al-ishlah: Jurnal Pendidikan. 2(1) 2019. 